\title{
RABIES REVIEW: IMMUNOPATHOLOGY, CLINICAL ASPECTS AND TREATMENT
}

\author{
CONSALES C. A. (1), BOLZAN V. L. (1) \\ (1) Pasteur Institute, São Paulo, Brazil.
}

\begin{abstract}
Among the diseases of viral origin, rabies is unique in its distribution and range of victims since it can afflict all warm-blooded animals. The interaction between the virus and the host population has facilitated the survival of the disease. The rabies virus (RV) has not changed in any significant way and has been capable of taking advantage of conditions suited to the continuance of rabies. Infection by RV is invariably lethal in the absence of protective immune response which, however, can contribute to the pathogenesis of rabies. Proinflammatory cytokines might affect, directly or indirectly, the levels of neurotrophins, growth factors, neurotransmitters and neurotoxins in the brain by activating glia, neurons, and vascular and immune cells. Although understanding of the bases for neuronal dysfunction and neuronal death during RV infection has progressed, no fundamental abnormality has been identified so far.
\end{abstract}

KEY WORDS: rabies, immunopathology, clinical aspects, treatment.

CONFLICTS OF INTEREST: There is no conflict.

\section{CORRESPONDENCE TO:}

CLEIDE ASCHENBRENNER CONSALES, Instituto Pasteur, Av. Paulista, 393, 01311-000, São Paulo, SP, Brasil. Phone: +55 1132880088 ext. 108/116.

Email: cleide135@yahoo.com.br. 


\section{ETIOLOGY}

Lyssavirus is one of the seven genera that form the family Rhabdoviridae, within the order Mononegavirale. It comprises classical rabies virus (RABV; genotype 1), Lagos bat virus (LBV; genotype 2), Mokola virus (MKV; genotype 3), Duvenhage virus (DV; genotype 4), European bat lyssavirus 1 (EBLV-1; genotype 5), European bat lyssavirus 2 (EBLV-2; genotype 6), and Australian bat lyssavirus (ABLV; genotype 7). Recently, four additional viruses, isolated from insectivorous bats, have been proposed as new members of Lyssavirus genus: Aravan virus (AV), Khujand virus (KV), Irkut virus (IV), and West Caucasian bat virus (WCBV) $(10,33,60,97)$.

Rabies viruses are bullet-shaped structures of about $75 \mathrm{~nm} \times 200 \mathrm{~nm}$ and can be roughly divided into a structural and a functional unit: the viral envelope and the ribonucleocapside core. Five monocistronic genes relate to five viral proteins: The $\mathrm{N}$ gene codes for a nucleoprotein that encapsulates the viral and the unsegmented negative-stranded RNA. The P gene produces a phosphoprotein, which is important not only for transcription and replication but also for interactions with cellular protein components during axoplasmic transport. The $\mathrm{M}$ gene codes for a matrix protein. The $G$ gene produces a single transmembrane glycoprotein which is assembled as a trimeric spike. This glycoprotein is responsible for the initial binding during infection of susceptible cells and is the only target for virus-neutralizing antibodies. The $L$ gene encodes a polymerase for RNA synthesis $(11,81)$.

\section{RABIES TRANSMISSION}

The commonest way of rabies transmission is by the bite of an infected mammal (Figure 1) (2). 


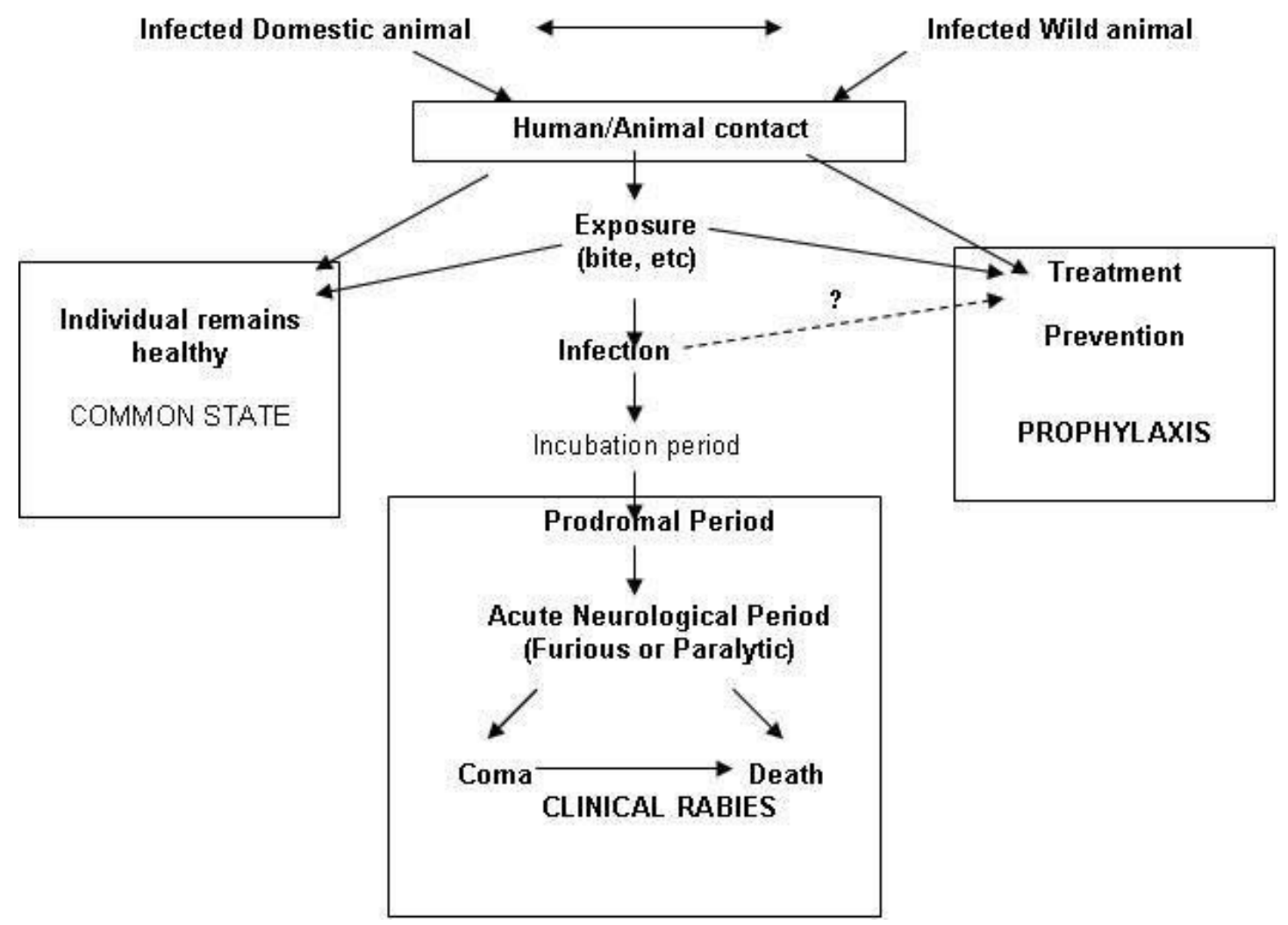

Figure 1: Course of rabies transmission. The first step is the transmission of the disease following exposure. The incubation period varies greatly. It ends when the virus begins to spread from the bite site to the surrounding peripheral nerves. Adapted from Baer et al., (2).

Bites by rabid animals generally inoculate virus-laden saliva through the skin into muscle and subcutaneous tissues (94). Other inoculation routes are rare. Rabies virus entry occurs through wounds or direct contact with mucosal surfaces. The virus cannot cross intact skin. The risk of rabies infection by a bite (5\%-80\%) is at least 50 times greater than that by a scratch (0.1\%-1\%) (45).

Mortality after untreated bites by rabid dogs ranges from $38 \%$ to $57 \%$ and depends on the severity and location of the wound as well as on the presumed virus concentration in the saliva $(45,94)$.

Bat virus might be more infectious when inoculated superficially into the epidermis since it replicates more rapidly in non-neuronal cells and at lower temperatures than do dog rabies viruses. Percutaneous infection probably occurs during unnoticed skin contact, which may result in a minute bite. The route of viral entry into epithelial nerves and eventually into the central nervous system (CNS) is unknown $(23,65)$. 
Inhalation of aerosolized RV occurred accidentally in laboratories of vaccine production (102) or in caves inhabited by numerous infected bats (36). Infection through the digestive tract has also been reported $(16,19)$.

Contact with animal vaccines may be significant when attenuated vaccine is used. In these situations, rabies prophylaxis is necessary. The handling and skinning of infected carcasses can be of risk for workers in refrigeration plants and butchers' shops, and veterinarians.

The contact with infected people could be a potential risk for their relatives and health workers when unprotected direct contact with secretions from a patient containing viable virus occurs $(30,44)$.

There are many reports of organ transplantation involved in the transmission of rabies. The most frequent cases have been observed in corneal transplantation (53). The most recent case reported was of a German patient and occurred in 2005 (43, $54)$.

In 2004, the Centers for Disease Control (CDC) in the United States confirmed the first case of rabies transmission through solid organ transplantation by testing autopsy samples after the death of 4 patients who received organ transplants (two kidney receptors, one liver receptor, and one receptor of an arterial segment) from the same donor. Subsequently, it was learned that a bat had bitten the donor (83). Three other cases of rabies-related organ transplantation were reported in Germany in 2005. These three patients received lung, kidney and kidney/pancreas transplants following the donor's death (43).

Before transplantation, the donor (if possible) and his relatives and friends should be questioned as to any history of physical contact with bats or bites by them or other mammals anywhere in the world. Patients with such a history should not be accepted as donors, even if post-exposure prophylaxis was carried out. There are no suitable screening tests to distinguish whether potential donors are infected. It has been recommended that donors, particularly those with neurological symptoms, should be screened for rabies (24).

So far, cases of rabies infection via blood transfusion have not been reported and rabies viraemia has not been demonstrated in animals or men. The virus seems to be strictly intra-neuronal during the incubation phase of the disease. There are no evidences that apparently healthy blood donors can transmit rabies, even if they incubate the infection. The one-year deferral of donation following post-exposure 
rabies prophylaxis remains a reasonable precaution (54). In Brazil, the Sanitary Surveillance Center (ANVISA) has decided that the interval between rabies postexposure treatment and blood donation should be one year and that for rabies preexposure vaccination, 4 weeks (12).

The RV migrates along peripheral nerves (via the fast axonal transport system) towards the CNS at about $50-100 \mathrm{~mm}$ per day. This movement is strictly retrograde, which indicates infection is via sensory and motor nerves. Invasion of the CNS by the RV glycoprotein may not occur via the sensory nerve pathway (Figure 2) (64).

\section{Host Cell (Neuron) Infection}

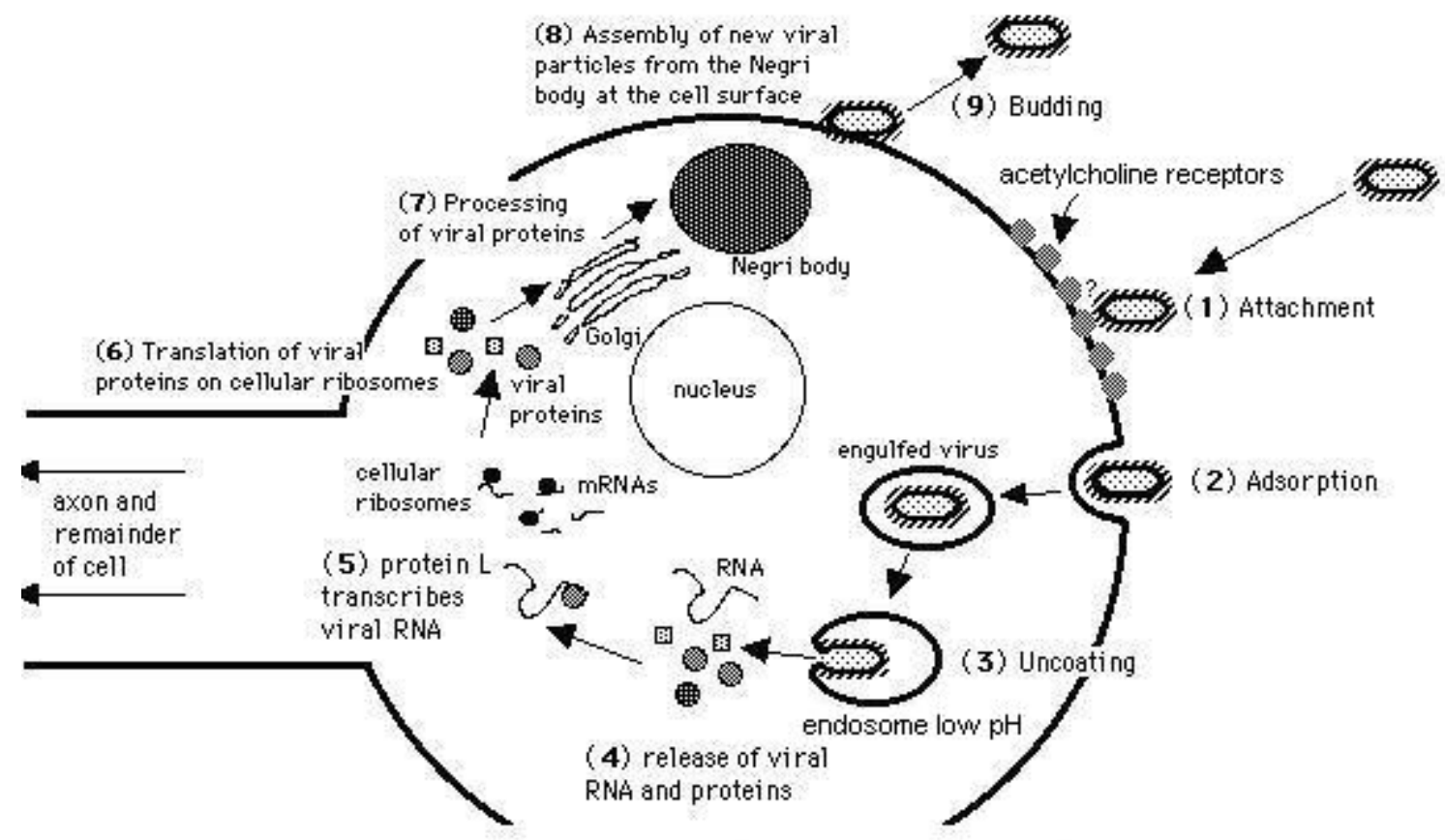

Figure 2: Cycle of viral infection and replication. Adapted from Mazarakis et al. (64).

The incubation period or eclipse phase varies from 2 weeks to 6 years (average: 2 to 3 months) according to the amount of viral inoculum and the inoculation site. Bites on the head, face, neck and hands, particularly together with bleeding, offer the highest risk and are generally associated with a shorter incubation period. The RV can stay in the muscle tissue for long periods and in certain circumstances, its long persistence may provide an opportunity for host immune clearance and postexposure treatment $(45,94)$. 


\section{IMMUNOPATHOLOGY}

One of the most surprising aspects of rabies immunopathology is the almost complete lack of an inflammatory response within the CNS characterized by perivascular cuffing with mononuclear cells, local gliosis and neuronophagia. Lesions occur in most areas of the CNS but are frequently more severe in the brainstem. This contrasts with other viral diseases of the CNS, in which inflammation is the major pathological characteristic. These observations suggest that neuronal dysfunction, rather than neuronal death, is probably responsible for the fatal outcome of rabies under normal conditions.

Contrasting with the protective role of immunity, immune mechanisms (even those generally thought to be protective) often have pathological attributes depending on the extent of the infection when immune effectors come into play. This is the case of reactions occurring in the nervous tissue. The anti-RV immune response elicited after exposure to the virus can prevent rabies, indicating that the pathogenicity of a particular RV strain may depend on its capability to spread without inducing a protective immune response. The virus neurotropism is probably a key element in this process, as CNS tissues are naturally sequestered from the immune system. Other aspects of the RV nature clearly have a major impact on the virus capacity to induce a protective antiviral immune response, which has been extensively studied $(48,55,103)$.

Viral glycoprotein is the target for most RV-neutralizing antibodies and has been a strong inducer of apoptosis in infected cells, which is evidently an immunogenic process in rabies $(28,79)$. If an immune response to rabies develops either inappropriately or after the infection has spread sufficiently, an extensive immunemediated damage of CNS tissues could be expected (49).

Researches using mice showed that when the infection route were the extremities such as the mouse footpad, peripheral nerve damage was more likely to occur leading to paralytic rabies with some prospects of survival; differently from lethal encephalitic rabies following intracerebral infection by the same strain (84).

The possibility that immunity contributes to the pathogenesis of rabies is also supported by what has been termed the "early death" phenomenon, in which inadequately immunized mice may die more rapidly of rabies than unvaccinated controls. Insights into the contribution of the immune response to the accelerated death of RV-infected animals result from classic experiments in which 
immunocompromised mice survived RV infection for longer periods than normal animals. However, immunosuppression can increase the overall mortality. Clinical signs of rabies and death were accelerated in immunosupressed mice when immune serum was administered or the immune response to rabies re-appeared, suggesting that an antiviral antibody can contribute to rabies immunopathogenesis $(78,82)$.

Pathological aspects of the immune reactivity in the CNS are sufficient to explain the contribution of immune responses to rabies pathogenesis. However, there is another potential contribution that has not been examined in great detail: elements of either the adaptive or the innate immune response may directly or indirectly stimulate the virus replication and dissemination. Evidences that cells of the immune system are infected (90) suggest that such cells might transport the virus from poorly to highly innervated areas such as the lymph nodes, facilitating the RV spread to the CNS. This could explain how the RV can enter the nervous system when introduced via organ transplants, as has recently occurred (15).

Cells of the immune and central nervous systems may share similar functions: secretion of immunoregulatory cytokines, response to cytokines, and antigen presentation. These properties allow physical contact between the two systems, i.e. microglia and/or astrocytes presenting antigens to T cells, and communication with soluble factors such as cytokines. There is a complex circuit of interactions mediated by cytokines, especially during lymphoid/mononuclear cell infiltration into the CNS. Secretion of IFN- $\gamma$ by infiltrating activated T cells could initially induce astrocytes and microglia to express class I and class II major histocompatibility complex (MHC) antigens, and to prime these class I and class II MHC antigens for subsequent cytokine production. The activation of astrocytes and microglia may contribute to the initiation and/or propagation of intracerebral immune and inflammatory responses. A number of mediators present in the CNS, such as prostaglandin, cytokines IFN- $\alpha$, IFN- $\beta$ and IFN- $\gamma$, and endogenous neuropeptides like norepinephrine and vasointestinal peptides, can suppress these responses by inhibiting both class I and class II MHC expression and cytokine production by glial cells. The induction and ultimate downregulation of the immune response and cytokine production within the CNS is dependent on: a dynamic interaction between a variety of peripheral immune and CNS cells; the activation status of these cells; the presence of cytokines with pleiotropic effects (IFN- $\gamma$, IL-1, IL-6, IFN- $\alpha$, and others); the concentration and 
location of these cytokines in the CNS; and the temporal sequence in which a particular cell responds to the cytokines (6).

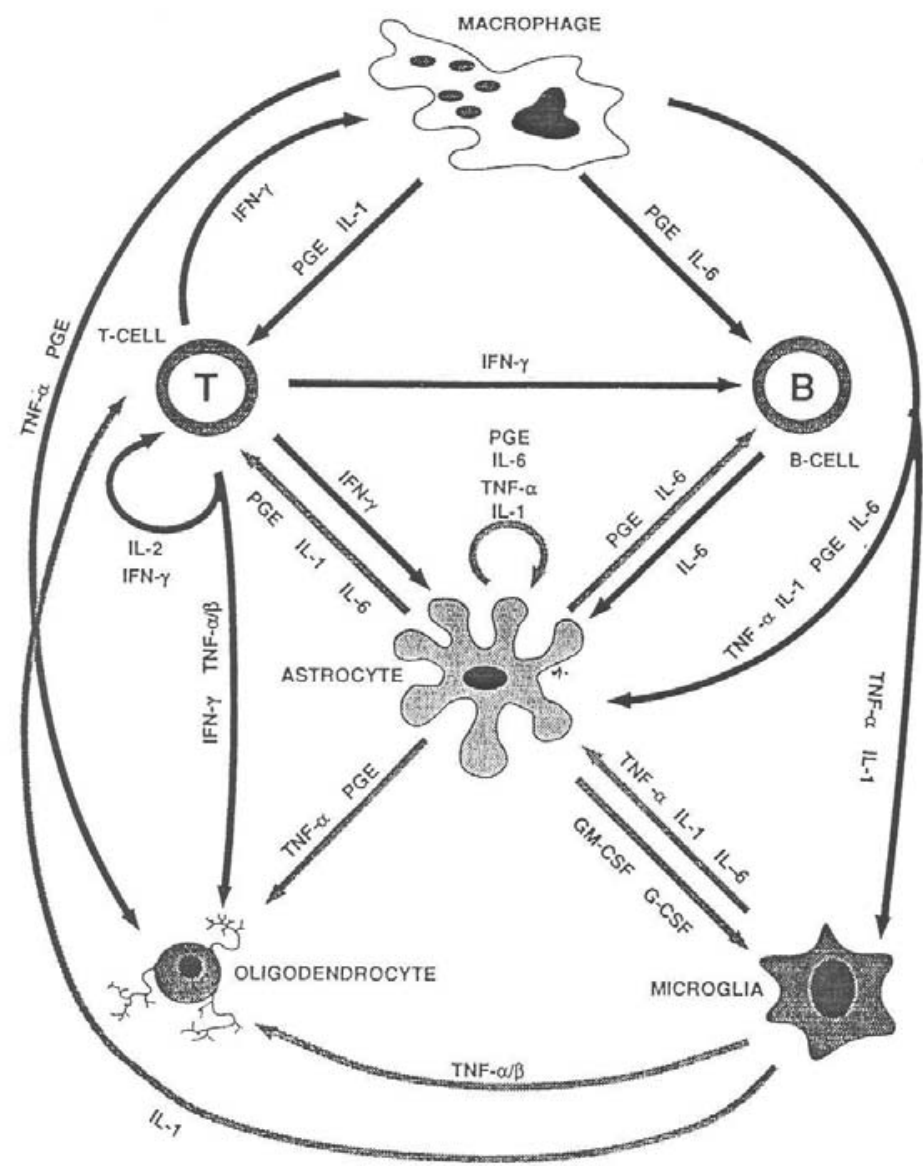

Figure 3: Potential interactions between cells of the immune system ( $T$ and $B$ cells, and macrophages) and those of the central nervous system (astrocytes, microglia and oligodendrocytes). Solid arrow: cytokine effects mediated by immune system cells. Stippled arrows: cytokine effects mediated by nervous system cells. Adapted from Benveniste (6).

The cause of functional alterations in RV-infected neurons is not clear yet. Experimental studies have investigated possible abnormalities in the neurotransmission involving acetylcholine $(25,50,92)$. Defective neurotransmission involving neurotransmitters other than acetylcholine could be important in the pathogenesis of rabies, and both serotonin and gamma-aminobutyric acid (GABA) have been studied (14).

Neurotransmission essentially involves four steps, namely: synthesis, storage, release and interaction with postsynaptic receptors, and intracellular events (71). Measurement of one, some, or all of the aspects of neurotransmission has been used as an indicator of neuronal activity (35). Koprowski et al. have hypothesized 
that the nitric oxide neurotoxicity may mediate neuronal dysfunction in rabies and induction of inducible nitric oxide synthase (iNOS) mRNA in mice experimentally infected with street RV $(59,93)$. Neurotropic viruses may cause cell death through either apoptosis or necrosis. Apoptosis depends on the synthesis of macromolecules and requires energy whereas necrosis is associated with energy failure $(29,40)$.

Apoptosis is induced via both virus-dependent and cell-dependent mechanisms. In RV infection, complex mechanisms may be involved in the death or survival of neurons both in vitro and in vivo using different viral strains and inoculation routes. Both in vitro and in vivo observations demonstrated that apoptosis might be a protective rather than a pathogenic mechanism in $\mathrm{RV}$ infections because few pathogenic viruses induced more apoptosis than a higher number of pathogenic viruses both in vitro and in vivo using peripheral inoculation routes. Thus, preservation of the neurons and limitation of such network by inhibiting apoptosis and limiting inflammation and destruction of T cells that invade the CNS in response to the infection is crucial for the RV neuroinvasion and transmission to another animal $(3,79)$.

\section{CLINICAL MANIFESTATIONS}

Human rabies may manifest in encephalitic (furious) or paralytic (dumb) forms. The brainstem is involved in both clinical forms, although there are no clinical signs of dysfunction in this portion of the brain. Differences in the tropism at the inoculation site or in the CNS, in the dissemination route, or in the triggering of the immune cascade in the brainstem may account for clinical variations (45).

Classical signs of brain involvement include spasms in response to tactile, auditory, visual or olfactory stimuli (aerophobia and hydrophobia) alternating with periods of lucidity, agitation, confusion and signs of autonomic dysfunction. Spasms occur in almost all rabid patients in whom excitation is prominent. However, spontaneous inspiratory spasms usually occur continuously until death. Excitation is less evident in paralytic rabies, and phobic spasms appear in only $50 \%$ of these patients (97). Clinical features may be divided into 5 stages: incubation period, prodrome, acute neurological phase, coma, and death (Table 1). 
Table 1: Natural history of rabies in humans. Hypothetical composite case. Not all clinical abnormalities are necessarily present in every case. Adapted from Fishbein and Robinson (32).

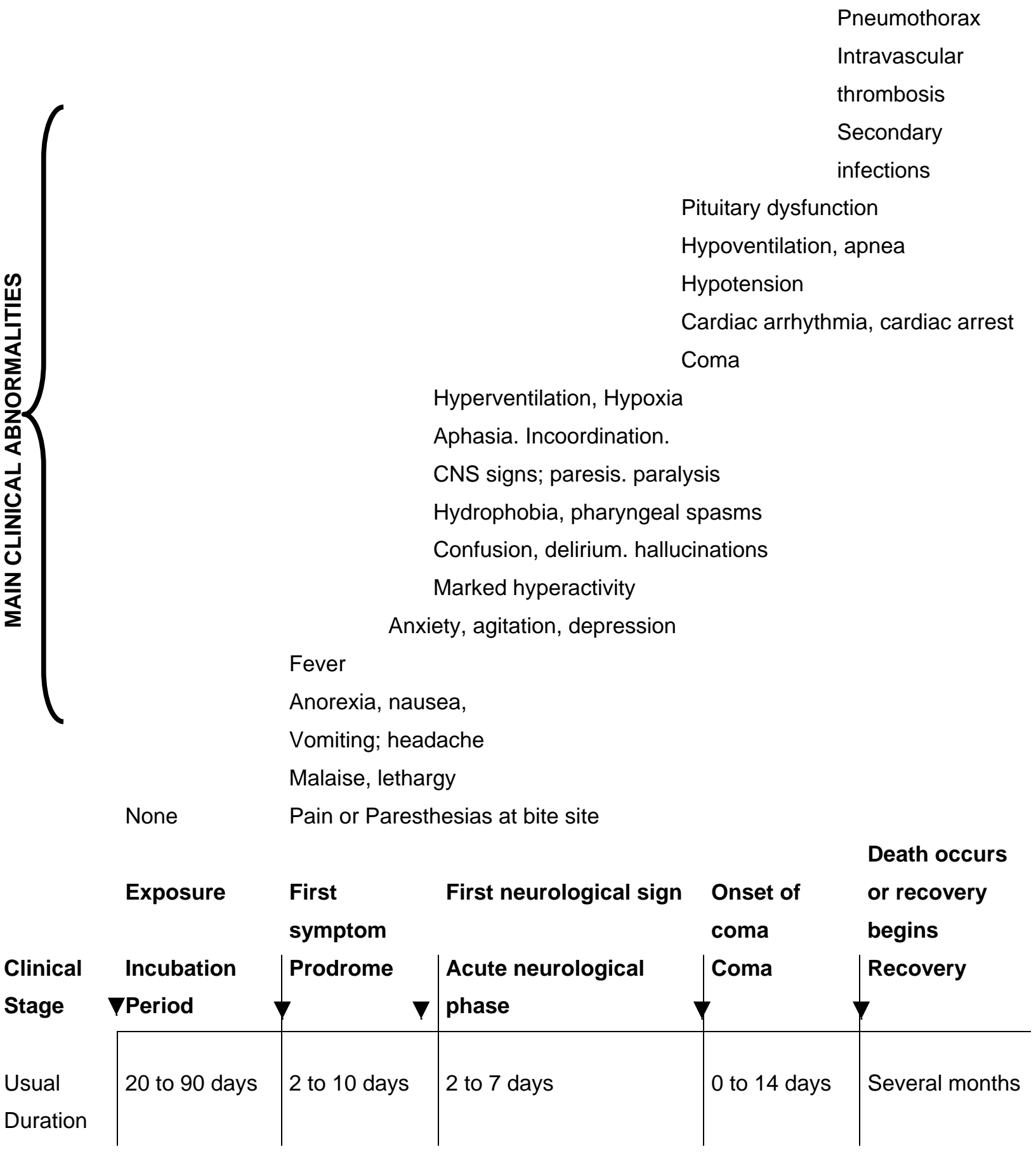

Non-classical symptoms can be observed in patients with bat-related rabies and consist of neuropathic pain, radicular pain, objective sensory or motor deficits, and choreiform movements of the bitten limb during the prodromal phase. Both focal brainstem signs and myoclonus are common. Localized signs like hemiparesis or hemisensory loss, ataxia, Hener's vertigo syndrome, convulsive and non-convulsive 
seizures, and hallucinations are frequent. Myoclonus and hemichorea, agitation at night and calm during the day, repeated spontaneous ejaculation, paraphasia, facial and bulbar weakness with preserved arm strength, or bilateral weakness may occur. Patients do not present phobic spasms or autonomic hyperactivity. During coma, inspiratory spasms increase; in the paralytic form, weakness is intense. Viral involvement at the sinus or atrioventricular node, myocarditis as well as changes in the cardiac rhythm and function may happen. Coma precedes circulatory insufficiency, a prime cause of death. Hematemesis occurs in $30 \%-60 \%$ of patients approximately 6 hours before death (46). Renal dysfunction is secondary to dehydration (22).

\section{RABIES DIAGNOSIS}

Laboratory diagnosis of rabies in humans and animals is essential for timely postexposure prophylaxis $(45,47)$. Rabies diagnosis may be carried out either in vivo or postmortem (Table 2) (94).

Table 2: Diagnosis of human rabies.

\begin{tabular}{|c|c|c|}
\hline SPECIMEN & TEST & DETECTION \\
\hline \multicolumn{3}{|l|}{ ante mortem } \\
\hline $\begin{array}{l}\text { skin punch biopsy; repeat until a } \\
\text { diagnosis is obtained }\end{array}$ & $\begin{array}{l}\text { FAT test on frozen section } \\
\text { RT-PCR }\end{array}$ & $\begin{array}{l}\text { antigen detection } \\
\text { viral RNA } \\
\text { virus isolation }\end{array}$ \\
\hline \multirow{2}{*}{$\begin{array}{l}\text { saliva, tears, CSF; repeat until a } \\
\text { diagnosis is obtained }\end{array}$} & Tissue culture & \\
\hline & $\begin{array}{l}\text { Suckling mouse inoculation } \\
\text { RT-PCR }\end{array}$ & $\begin{array}{l}\text { virus isolation } \\
\text { viral RNA }\end{array}$ \\
\hline \multirow[t]{2}{*}{ serum } & & antibody detection \\
\hline & Unvaccinated; test immediately* & \\
\hline \multirow[t]{3}{*}{ CSF } & $\begin{array}{l}\text { Vaccinated; save and compare a few } \\
\text { days later }\end{array}$ & antibody detection \\
\hline & test immediately with serum* & \\
\hline & & antibody detection \\
\hline \multicolumn{3}{|l|}{ postmortem } \\
\hline brain & FAT test of impressions smear & Antigen detection \\
\hline needle necropsy** of two or & RT-PCR & Viral RNA \\
\hline $\begin{array}{l}\text { more samples (brainstem and } \\
\text { cerebellum) }\end{array}$ & suckling mouse inoculation & Viral isolation \\
\hline retrospective diagnosis & enzyme methods & $\begin{array}{l}\text { antigen detection in } \\
\text { formalin-fixed tissue }\end{array}$ \\
\hline \multicolumn{3}{|c|}{$\begin{array}{l}\text { * In unvaccinated patients, rabies antibody generally appears in the second week of the disease. Rabies specific IgM has been } \\
\text { detected in the serum and in some cases in the CSF at low concentration, but no earlier than IgG. High concentrations of } \\
\text { antibody in the CSF have been considered diagnostic despite vaccination. } \\
\text { ** Needle necropsy: with a Vim-Silverman's or other long biopsy needle. } \\
\text { Source: Warrell and Warrell, } 2004 \text { (94). }\end{array}$} \\
\hline
\end{tabular}


Serological tests may help but RV antibodies have been detected in only $20 \%$ of unvaccinated rabies patients tested 1-26 days after the onset of the disease. Antibodies appear in the cerebrospinal fluid later $(47,48)$.

Skin biopsy samples are usually taken from the nuchal area containing hair follicles with peripheral nerves. Examination of at least 20 sections is recommended to detect rabies nucleocapside inclusions around the hair follicles. Sensitivity is $82 \%$ when the test is carried out within 4 days after the onset of the disease and $60 \%$ when it is performed between 5 and 8 days after infection (47).

Corneal imprint using fluorescent antibody technique can be carried out for detection of RV antigen. Results depend on the quality of the material sent to the laboratory. Sensitivity is around $42 \%$ and specificity, $100 \%$ (58).

Brain biopsy is not practicable, nor is it recommended for the diagnosis of rabies, but it could be of high sensitivity (47). False negative results may occur when biopsy of the frontal and temporal regions is carried out on the first day of the disease.

Laboratory tests of secretions and biological fluids such as saliva, spinal fluid, tears, and tissues may be used to diagnose rabies. The specimens should be stored at $20^{\circ} \mathrm{C}$ or below. A positive result is indicative of rabies but a negative result does not rule out the possibility of infection (97). Such specimens can be used to detect the RV using intracranial inoculation into mice or neuroblast cell cultures, and to detect the virus RNA using reverse transcription polymerase chain reaction. Serial samples should be tested since not all of them are positive due to the intermittent shedding of the virus $(21,45)$.

Molecular detection using polymerase chain reaction (PCR) and nucleic acid sequence-based amplification techniques shows the highest level of sensitivity but can produce false positive or false negative results and should only be used in combination with other conventional techniques. Virus identification using molecular techniques is of epidemiological importance. Studies on molecular virology have permitted the classification of lyssavirus in genotypes and demonstrated the virus isolation from a particular geographic area $(9,91,96)$. Indirect immunofluorescence uses a panel of antinucleocapsid monoclonal antibodies for antigenic typing, which is provided by the Centers for Disease Control and Prevention (CDC), Atlanta, USA (97). 


\section{POSTMORTEM DIAGNOSIS}

Brain tissue specimens are the preferred sampling for postmortem diagnosis in both humans and animals. In cases where brain tissue is not viable, other tissues may be of diagnostic value; also, other routes such as transorbital or trans-foramen magnum should be used to obtain brain tissue. To preserve tissues refrigeration, glycerin can be used. Dried smear of brain tissue can be kept on filter papers when safe transportation of the infected material is possible (97).

The amount of antigens has varied among different regions of the brain (7). The thalamus, pons and medulla can be considered the most reliable parts of the brain, as they were positive in all the specimens tested. The cerebellum, hippocampus and other parts of brain were negative in $4.5 \%, 4.9 \%$, and $3.9 \%-11.1 \%$, respectively, out of positive brains. The thalamus was positive in all specimens and had the most frequent prevalence (97.8\%) of abundant antigens.

Antigen detection may be performed using the fluorescent antibody test (FAT), a rapid and sensitive method to diagnose rabies infection in animals and humans. This is the gold standard for rabies diagnosis. However, FAT can lead to a false negative result when bat or horse specimens are involved (61). Virus isolation may be necessary to confirm the results of antigen detection tests and for further characterization of the isolate using intracranial inoculation into mice or neuroblast cells. Molecular detection using PCR and other amplification techniques are not currently recommended for routine postmortem diagnosis of rabies (96).

\section{DIFFERENTIAL DIAGNOSES}

Differential diagnosis of rabies includes: encephalitis caused by arboviruses such as Japanese, Eastern equine and West Nile viruses, enteroviruses, Nepah virus, and Herpes virus; acute hepatic porphyria with neuropsychiatric disturbances and signs of autonomic dysfunction; substance abuse like alcohol withdrawal or delirium tremens; acute serotonin syndrome due to administration of serotonin uptake inhibitors; tetanus; Guillain-Barré syndrome; transverse myelitis; neuroparalytic accidents, when the patient is from a country where nerve-type vaccines are used; psychiatric disturbances; cerebrovascular accidents; epilepsy; poisoning by atropinelike compounds; poliomyelitis; and intracranial mass $(31,96,97)$. 


\section{MANAGEMENT OF RABIES IN HUMANS}

Efforts to prevent fatal outcome have failed, and no spontaneous recovery has been observed (96). Rabies in humans progresses to death five to seven days after the onset of symptoms. Medical management may prolong survival by 133 days (26). Treatment seems to be incapable of changing the evolution to death.

Treatment is basically to comfort the patient and his/her family. Rabies experts have recommended that the approach to rabies encephalitis management be only palliative. The following characteristics and resources could be considered favorable for an aggressive therapy: administration of any rabies vaccine before the clinical onset of rabies; manifestation of the disease at a very early stage, with minimal neurological symptoms or signs; previously good health and absence of chronic diseases; relatives who accept both the high probability of an unsuccessful outcome and the possibility of neurological disability in a rabies survivor; and access to appropriate resources and facilities (38).

Therapy should combine antiexcitatory and antiviral drugs as well as intense care while natural native immune response combats the viral infection (52); rabies vaccine at multiple sites by intradermal route (the intramuscular route takes at least one week to produce immunity and the intradermal route accelerates the immune response); rabies immunoglobulin (human or equine rabies immunoglobulin can lead to viral clearance); monoclonal antibodies (RV-neutralizing antibodies by intravenous and intrathecal route); ribavirin and amantadine (in vitro antiviral activity) (87); interferonalpha (administered by intravenous and intrathecal route through the Ommaya reservoir); ketamine (an anesthetic agent that has anti-rabies activity by interacting with N-methyl-D-aspartate receptor antagonist) $(62,77)$; benzodiazepines and barbiturates (GABA-receptor agonists and induced therapeutic coma reduce the brain excitatory metabolism and autonomic reactivity). Corticosteroids should not be used (in mouse models, the use of corticosteroids increased the mortality rate and shortened the incubation period) (27). Severe edema associated with risk of brain herniation is rare in rabies patients, although this is a possible complication in intrathecal therapy using human rabies immunoglobulin. Therefore, administration of corticosteroids is not recommended for rabies therapy, except for the treatment of adrenocortical insufficiency. Corticosteroids may reduce the passage of therapeutic agents through the blood brain barrier (4). 
Although rabies has been considered 100 per cent fatal, there are well-documented reports of animal survivals and six cases of human survival. Such patients received immunoprophylaxis before the onset of symptoms $(39,42)$. All these cases were of the paralytic type and diagnosed using indirect evidence of high titers of rabies specific antibodies in the cerebral spinal fluid; however, neither the virus nor the viral antigen was demonstrated (Table 3) (94).

Table 3: Human recovery from rabies encephalitis.

\begin{tabular}{|c|c|c|c|c|c|}
\hline $\begin{array}{c}\text { PATIENT } \\
\text { AND } \\
\text { REFERENCE }\end{array}$ & EXPOSURE & TREATMENT & $\begin{array}{c}\text { INCUBATION } \\
\text { PERIOD AND } \\
\text { COMPLICATIONS }\end{array}$ & DIAGNOSIS & OUTCOME \\
\hline $\begin{array}{l}\text { 9-year-old } \\
\text { boy, Ohio, } \\
\text { USA, } 1970 \\
(42)\end{array}$ & $\begin{array}{l}\text { Thumb bite } \\
\text { by rabid big } \\
\text { brown bat }\end{array}$ & $\begin{array}{l}\text { Duck-embryo } \\
\text { vaccine without } \\
\text { rabies } \\
\text { immunoglobulin } \\
\text { on the following } \\
\text { day }\end{array}$ & $\begin{array}{l}20 \text { days. } \\
\text { Encephalitis, } \\
\text { paralysis, coma, } \\
\text { cardiac arrhythmia }\end{array}$ & $\begin{array}{l}\text { High } \\
\text { concentration } \\
\text { of antibodies } \\
\text { in the CSF } \\
\text { and serum }\end{array}$ & $\begin{array}{l}\text { Intensive care, } \\
\text { complete } \\
\text { recovery in } 6 \\
\text { months }\end{array}$ \\
\hline $\begin{array}{l}\text { 45-year-old } \\
\text { woman, } \\
\text { Argentina, } \\
1972 \\
(76)\end{array}$ & $\begin{array}{l}\text { Bite by } \\
\text { clinically } \\
\text { rabid dog } \\
\text { which died } 4 \\
\text { days later }\end{array}$ & $\begin{array}{l}\text { Suckling- } \\
\text { mouse brain } \\
\text { rabies vaccine } \\
10 \text { days later }\end{array}$ & $\begin{array}{l}21 \text { days. } \\
\text { Cerebellum } \\
\text { dysfunction, } \\
\text { quadriparesis, } \\
\text { varying levels of } \\
\text { consciousness, } \\
\text { cardiac arrhythmia }\end{array}$ & $\begin{array}{l}\text { High } \\
\text { concentration } \\
\text { of antibodies } \\
\text { in the CSF } \\
\text { and serum }\end{array}$ & $\begin{array}{l}\text { Recovered but } \\
\text { relapsed twice } \\
\text { after vaccine } \\
\text { boosters, slow } \\
\text { resolution over } \\
1 \text { year }\end{array}$ \\
\hline $\begin{array}{l}\text { 32-year-old } \\
\text { man, New } \\
\text { York, USA, } \\
1977 \\
(17)\end{array}$ & $\begin{array}{l}\text { Inhaled } \\
\text { aerosol of } \\
\text { fixed rabies } \\
\text { virus, SAD } \\
\text { strain, in } \\
\text { laboratory }\end{array}$ & $\begin{array}{l}\text { Only pre- } \\
\text { exposure duck- } \\
\text { embryo cell } \\
\text { vaccine }\end{array}$ & $\begin{array}{l}21 \text { days. } \\
\text { Encephalitis, } \\
\text { spastic } \\
\text { hemiparesis, } \\
\text { impaired } \\
\text { consciousness }\end{array}$ & $\begin{array}{l}\text { High } \\
\text { concentration } \\
\text { of antibodies } \\
\text { in the CSF } \\
\text { and serum }\end{array}$ & $\begin{array}{l}\text { Gradual } \\
\text { improvement, } \\
\text { personality } \\
\text { disorder, } \\
\text { dementia }\end{array}$ \\
\hline $\begin{array}{l}\text { 9-year-old } \\
\text { boy, Mexico, } \\
1992 \\
\text { (1) }\end{array}$ & $\begin{array}{l}\text { Head bite } \\
\text { by rabid dog }\end{array}$ & $\begin{array}{l}\text { Vero-cell } \\
\text { vaccine without } \\
\text { rabies } \\
\text { immunoglobulin } \\
\text { on the following } \\
\text { day }\end{array}$ & $\begin{array}{l}19 \text { days. } \\
\text { Encephalitis, } \\
\text { convulsions, deep } \\
\text { coma, } \\
\text { quadriplegia }\end{array}$ & $\begin{array}{l}\text { High } \\
\text { concentration } \\
\text { of antibodies } \\
\text { in the CSF } \\
\text { and serum }\end{array}$ & $\begin{array}{l}\text { Slight } \\
\text { improvement, } \\
\text { reaction to } \\
\text { painful stimuli, } \\
\text { blindness and } \\
\text { deafness, } \\
\text { death after } 34 \\
\text { months }\end{array}$ \\
\hline $\begin{array}{l}\text { 6-year-old } \\
\text { girl, India, } \\
2000 \\
(63)\end{array}$ & $\begin{array}{l}\text { Face and } \\
\text { hand bites } \\
\text { by stray dog } \\
\text { which died } 4 \\
\text { days later }\end{array}$ & $\begin{array}{l}\text { No wound } \\
\text { cleaning, chick- } \\
\text { embryo rabies } \\
\text { vaccine without } \\
\text { rabies } \\
\text { immunoglobulin } \\
\text { on the same } \\
\text { day }\end{array}$ & $\begin{array}{l}16 \text { days. } \\
\text { Hallucinations, } \\
\text { coma, } \\
\text { hydrophobia, focal } \\
\text { seizures }\end{array}$ & $\begin{array}{l}\text { High } \\
\text { concentration } \\
\text { of antibodies } \\
\text { in the CSF } \\
\text { and serum }\end{array}$ & $\begin{array}{l}3 \text { months of } \\
\text { coma, slow } \\
\text { improvement } \\
\text { Spasticity, } \\
\text { tremors and } \\
\text { involuntary } \\
\text { movements } \\
\text { after } 18 \\
\text { months }\end{array}$ \\
\hline
\end{tabular}


The first case of human survival after rabies, without administration of rabies vaccine or immunoglobulin, was reported in 2004. A fifteen-year-old girl developed clinical rabies one month after she had been bitten by a bat (101). The possibility that the survival was due to an unusual but more moderate or attenuated variant of the virus, or to a rare host polymorphism, cannot be ruled out (51).

\section{RABIES PROPHYLAXIS}

After exposure to the RV, the most effective treatment should be used to combat the disease. Therapy must begin as soon as possible. Prophylaxis consists of the wound care and vaccination associated or not with rabies immunoglobulin (96).

During the management of a case of exposure to the $R V$, it is important to examine the wound and the immune situation of the patient (considering previous rabies) as well as to evaluate the animal involved in the accident (including a laboratory diagnosis of rabies) and the transmission area $(13,20)$.

The wound must be washed with soap and water and treated with an antiseptic solution that has antiviral properties, such as povidone-iodine or ethanol. The risk of rabies infection is higher in anatomical regions with a great concentration of nerve endings; when wounds are deep and present bleeding; and if lesions are extensive and numerous (96).

Antibiotic solutions are useless and may increase tissue irritation. Systemic antibiotic therapy will not prevent infection after bite wounds. It is only recommended for highrisk wounds such as deep punctures, i.e. those repaired surgically, and bites in the hands. Patients with a medical history of chronic disease such as diabetes, vascular disorders, prosthetic heart valves or presenting high risk of infection can be treated with antibiotics. Prophylactic antibiotics should be administered for 3 to 5 days. For cellulites, the treatment must continue from 10 to 14 days $(80,86)$.

According to the tetanus immunization status of the patient, tetanus prophylaxis may be necessary, and it may be simultaneous with rabies prophylaxis, including vaccination and anti-tetanus immunoglobulin.

\section{RABIES VACCINE}

There are many rabies vaccines already in use or undergoing evaluation around the world, and compared with HDCV (human diploid cell rabies vaccine, a gold standard 
of cell culture vaccine), they are less expensive to produce and more purified, showing greater effectiveness and weaker adverse reactions $(32,97)$.

An anti-rabies vaccine of cell culture for rabies prophylaxis has been used in São Paulo State since 2000 and throughout Brazil since 2003. A rabies vaccine produced from purified Vero cells (VEROCELL from Pasteur Merrieux, France) has also been used (20).

The Vero cell vaccine is produced in kidney cells from African green monkey using the Pitman-Moore virus strain inactivated with betapropiolactone (69). Each vaccine dose consists of $0.5 \mathrm{ml}$, and its potency is higher than $2.5 \mathrm{Ul} / \mathrm{ml}$ per dose. It must be kept under refrigeration at $2^{\circ} \mathrm{C}-8^{\circ} \mathrm{C}$.

Doses are the same for children, old people and immunossupressed patients. There is no contraindication for the use of such vaccine; it can be administered to children, pregnant women, and people who are ill or taking any kind of medicine (73).

Side effects of the rabies vaccine are frequently related to local reactions, fever, malaise, nausea, vomiting and headaches. Deaths due to the use of cell culture vaccine have never been reported.

Reports of neurological reactions associated with cell culture vaccine are rare in medical literature; they occur in approximately $1 / 500.000$ patients. Only six cases (prior to 1996) of neurological reactions such as weakness or paresthesias and permanent deficit of the deltoid muscle have been recorded. One patient developed a disease similar to multiple sclerosis. In the USA, the incidence of allergic reactions such as urticaria and anaphylaxis due to diploid cell rabies vaccine was $0.11 \%$ (11 cases out of 10,000 patients) (70).

Approximately $6 \%$ of people receiving booster vaccination may experience an immune complication such as a reaction characterized by urticaria, pruritus and malaise. Once initiated, post-exposure rabies prophylaxis should not be interrupted because of possible local or mild systemic reactions to the rabies vaccine $(18,95)$.

In Brazil, Butantan Institute has developed a new rabies vaccine from Vero cells adhered to microcarriers, cultured in a bioreactor in serum-free medium and infected with PV/Vero-Paris rabies virus strain. The virus suspension is purified through chromatography and rendered inactivate using betapropiolactone. Clinical tests (phases 1 and 2) carried out by Pasteur Institute, Sâo Paulo, have shown that the vaccine presents high safety, tolerability and immunogenic response (unpublished 
data). Neither fetal bovine serum nor albumin (human or bovine) was used in the preparation of this vaccine (34).

Intramuscular administration of rabies vaccine is the gold standard recommended by experts of The World Heath Organization (WHO). The subcutaneous route leads to a significant decrease in sera conversion rates and to a more rapid reduction in antibody response (72). The intradermal use of rabies vaccines is considered by WHO as an acceptable alternative regimen as it requires less amount of vaccine to produce a comparable degree of rabies protection $(73,74)$. Intradermal administration has become a standard practice in a number of countries throughout the world (95). The use of intradermal regimen is acceptable in Brazil only for preexposure treatment $(13,20)$.

The intradermal route should not be used for all patients. The vaccine should be administered by intramuscular route to patients who are immunocompromised or who are taking steroids or chloroquine. Furthermore, the use of chloroquine must be delayed for at least one month after vaccination if the intradermal route was used. Post-immunization antibody titers should be determined to ensure that an acceptable level was achieved $(20,96,97)$.

\section{HETEROLOGOUS RABIES IMMUNOGLOBULIN}

Rabies serum is a concentrated and purified solution of anti-rabies antibodies prepared from equines immunized with anti-rabies vaccine. In the past, anti-rabies sera were associated with numerous side effects, serum sickness, and anaphylactic reactions in about $40 \%$ of cases (56). Modern products, however, show low level of reaction. They are prepared through a specific purification process like enzymatic digestion, ammonia sulfate precipitation and thermocoagulation to remove any excess of protein $(13,20,99,100)$.

The serum must be kept under refrigeration at $2^{\circ} \mathrm{C}-8^{\circ} \mathrm{C}$, without freezing. The recommended dose is $40 \mathrm{IU}$ per kilogram of body weight. The most frequent presentation is $200 \mathrm{IU} / \mathrm{ml}$ in $10 \mathrm{ml}$ ampoules. Rabies serum must be injected preferably into or around the wound; the volume will depend on the anatomical region affected. It is recommended that all lesions be infiltrated with the serum $(96,97)$. Anaphylactic reactions are rare with rabies serum. They have been reported in less than $1 / 40,000$ cases. Reactions to heterologous rabies serum can be immediate or occur later. The most important immediate reaction is the anaphylactic shock, a rare 
condition that can occur within 2 hours after the serum administration. Later reactions may occur from 2 to 15 days after administration and may manifest as serum sickness or Arthus reaction. Their incidence varies from $1 \%$ to $6.2 \%(13,20)$. Less than $10 \%$ of the patients who received heterologous serum presented reaction at Pasteur Institute. The majority of cases of serum sickness occurred on day 7 in women around 40 years old (8).

The skin test is controversial. In medical literature, it has been considered of little value for prediction of reactions (88). It is not recommended by rabies experts of the Brazilian Ministry of Health because of the high number of false negative results. A detailed history of the patient is necessary to assess the risk of severe side effects that may follow anti-rabies serum administration. For patients at high risk of reaction, the use of human anti-rabies immunoglobulin (20 IU/ $\mathrm{kg}$ of body weight), available at the Special Immunobiological Reference Centers of the Immunization Programs of the Brazilian States, should be considered $(13,20)$.

\section{PRE-EXPOSURE RABIES VACCINATION}

Rabies prophylaxis can be recommended for people who foresee exposure to risky situations during their regular professional activities or travels to epidemic regions. Table 4 shows the criteria for pre-exposure rabies vaccination $(13,18,20)$. 
Table 4: Pre-exposure rabies vaccination.

\begin{tabular}{|c|c|c|c|}
\hline $\begin{array}{c}\text { RISK } \\
\text { CATEGORY }\end{array}$ & NATURE OF RISK & $\begin{array}{c}\text { TYPICAL } \\
\text { POPULATION }\end{array}$ & $\begin{array}{c}\text { PRE-EXPOSURE } \\
\text { REGIMEN }\end{array}$ \\
\hline Continuous & $\begin{array}{l}\text {-virus continuously } \\
\text { present, often in high } \\
\text { concentrations } \\
\text {-specific exposures likely } \\
\text { to be unrecognized } \\
\text {-bite, non-bite or aerosol } \\
\text { exposure }\end{array}$ & $\begin{array}{l}\text {-rabies research } \\
\text { laboratory workers, } \\
\text { rabies biologics } \\
\text { production workers }\end{array}$ & $\begin{array}{c}\text {-primary course of } \\
\text { vaccine ( } 3 \text { doses) } \\
\text {-serological test every } \\
6 \text { months } \\
\text {-booster vaccination* } \\
\text { if antibody titer is } \\
\text { below acceptable } \\
\text { levels }(<0.5 \mathrm{Ul} / \mathrm{ml})\end{array}$ \\
\hline Frequent & $\begin{array}{c}\text { - exposure usually } \\
\text { episodic with known } \\
\text { source, but exposure } \\
\text { might also be } \\
\text { unrecognized } \\
\text {-bite, non-bite or aerosol } \\
\text { exposure possible }\end{array}$ & $\begin{array}{c}\text {-rabies diagnostic } \\
\text { laboratory workers } \\
\text {-spelunkers } \\
\text {-veterinarians and staff } \\
\text {-animal control and } \\
\text { wildlife workers in rabies } \\
\text { epizootic areas }\end{array}$ & $\begin{array}{c}\text {-primary course of } \\
\text { vaccine ( } 3 \text { doses) } \\
\text {-serological test every } \\
\text { year } \\
\text {-booster vaccination if } \\
\text { antibody titer is below } \\
\text { acceptable levels (< } \\
0.5 \mathrm{Ul} / \mathrm{ml})\end{array}$ \\
\hline \multirow[t]{2}{*}{$\begin{array}{l}\text { Infrequent } \\
\text { (greater than } \\
\text { general } \\
\text { population) }\end{array}$} & $\begin{array}{c}\text {-exposure nearly always } \\
\text { episodic with known } \\
\text { source } \\
\text {-bite or non-bite } \\
\text { exposure }\end{array}$ & $\begin{array}{c}\text {-veterinarians } \\
\text {-animal control and } \\
\text { wildlife workers in areas } \\
\text { with low rabies } \\
\text { incidence } \\
\text {-veterinary students }\end{array}$ & $\begin{array}{c}\text {-primary course of } \\
\text { vaccine ( } 3 \text { doses) } \\
\text {-serological test every } \\
\text { year } \\
\text {-booster vaccination if } \\
\text { antibody titer is below } \\
\text { acceptable levels (< } \\
0.5 \mathrm{Ul} / \mathrm{ml})\end{array}$ \\
\hline & & $\begin{array}{l}\text {-travelers visiting areas } \\
\text { where rabies is enzootic } \\
\text { and the immediate } \\
\text { appropriate medical } \\
\text { care including biologics } \\
\text { is limited }\end{array}$ & $\begin{array}{l}\text { no serological test or } \\
\text { booster vaccination is } \\
\text { recommended }\end{array}$ \\
\hline $\begin{array}{l}\text { Rare (general } \\
\text { population) }\end{array}$ & $\begin{array}{l}\text { - exposure always } \\
\text { episodic with known } \\
\text { source } \\
\text {-bite or non-bite } \\
\text { exposure }\end{array}$ & $\begin{array}{l}\text {-general population, } \\
\text { including individuals in } \\
\text { rabies epizootic areas }\end{array}$ & $\begin{array}{l}\text {-no pre-exposure } \\
\text { immunization is } \\
\text { necessary }\end{array}$ \\
\hline
\end{tabular}

* Pre-exposure booster immunization consists of one dose of rabies culture cell vaccine (in Brazil, Vero cell rabies vaccine) injected into the deltoid area by intramuscular $(0.5 \mathrm{ml})$ or intradermal $(0.1 \mathrm{ml})$ route.

Sources: Costa et al., 1999 (20) and Brasil, Ministério da Saúde, 2004 (13).

\section{POST-EXPOSURE RABIES TREATMENT}

The recommended schedule is one dose of the vaccine injected into the patient's deltoid area on days $0,3,7,14$, and 28 . For children aged two years old or younger, the vaccine may be injected into the thigh muscles. The habits of the dog or cat involved in the accident must be evaluated. Treatment of humans may be unnecessary if the animals are considered of low risk for rabies transmission (e.g. animals living inside the houses, without any contact with other animals including bats). In accidents involving bats, it is always necessary to administer anti-rabies 
serum regardless of the lesion severity. A patient previously treated for rabies should be considered only for booster doses of the vaccine (Table 5) $(13,20)$.

Table 5: Post-exposure rabies treatment.

\begin{tabular}{|c|c|c|c|}
\hline & DOG OR & CAT (at the moment of & e accident) \\
\hline $\begin{array}{l}\text { Kind of } \\
\text { exposure }\end{array}$ & $\begin{array}{l}\text { Without rabies signs } \\
\text { or symptoms }\end{array}$ & $\begin{array}{c}\text { With clinical } \\
\text { suspicion of rabies }\end{array}$ & $\begin{array}{l}\text { With rabies; disappeared } \\
\text { or dead wild animals; } \\
\text { domestic animals of } \\
\text { economic value }\end{array}$ \\
\hline $\begin{array}{l}\text { Indirect contact } \\
\text { Contact with objects } \\
\text { contaminated by } \\
\text { suspected rabid } \\
\text { animals. }\end{array}$ & $\begin{array}{l}\text { Wash the site with soap } \\
\text { and water. } \\
\text { Treatment is not } \\
\text { recommended. }\end{array}$ & $\begin{array}{l}\text { Wash the site with } \\
\text { soap and water. } \\
\text { Treatment is not } \\
\text { recommended. }\end{array}$ & $\begin{array}{l}\text { Wash the site with soap } \\
\text { and water. } \\
\text { Treatment is not } \\
\text { recommended. }\end{array}$ \\
\hline $\begin{array}{l}\text { Slight accident } \\
\text { Bites or scratches } \\
\text { with teeth or nails } \\
\text { causing slight } \\
\text { wounds, small } \\
\text { extension and number } \\
\text { of lesions, on the } \\
\text { trunk and members } \\
\text { (except hands and } \\
\text { feet), and licking. }\end{array}$ & $\begin{array}{l}\text { Wash the site with soap } \\
\text { and water. } \\
\text { Observe the animal for } \\
10 \text { days post-exposure. } \\
\text { If animal remains } \\
\text { healthy during } \\
\text { observation period close } \\
\text { the case without } \\
\text { treatment. } \\
\text { If the animal disappears, } \\
\text { dies or becomes rabid, } \\
\text { start treatment } \\
\text { immediately with } 5 \\
\text { doses of rabies vaccine } \\
\text { on days } 0,3,7,14,28 \text {. }\end{array}$ & $\begin{array}{l}\text { Wash the site with } \\
\text { soap and water. } \\
\text { Start rabies vaccine } \\
\text { (on days } 0,3 \text { and } 7^{\star *} \text { ). } \\
\text { Observe the animal for } \\
10 \text { days post- } \\
\text { exposure. } \\
\text { If the animal remains } \\
\text { healthy during the } \\
\text { observation period, } \\
\text { stop vaccine. } \\
\text { If the animal } \\
\text { disappears, dies or } \\
\text { becomes rabid, } \\
\text { complete the treatment } \\
\text { with } 5 \text { doses of } \\
\text { vaccine. }\end{array}$ & $\begin{array}{l}\text { Wash the site with soap } \\
\text { and water. } \\
\text { Start the treatment with } 5 \\
\text { doses of rabies vaccine on } \\
\text { days } 0,3,7,14,28 \text {. }\end{array}$ \\
\hline Serious accident & $\begin{array}{l}\text { Wash the site with soap } \\
\text { and water. } \\
\text { Observe the animal for } \\
10 \text { days post-exposure. } \\
\text { Start treatment* with } 3 \\
\text { doses of vaccine on } \\
\text { days } 0,3 \text {, and } 7 \text {. } \\
\text { If the animal remains } \\
\text { healthy during the } \\
\text { observation period, stop } \\
\text { treatment. } \\
\text { If the animal disappears, } \\
\text { dies or becomes rabid, } \\
\text { continue treatment to } \\
\text { complete } 5 \text { doses of } \\
\text { rabies vaccine and use } \\
\text { heterologous anti-rabies } \\
\text { serum. }\end{array}$ & $\begin{array}{l}\text { Wash the site with } \\
\text { soap and water. } \\
\text { Observe the animal for } \\
10 \text { days post- } \\
\text { exposure. } \\
\text { Start treatment }{ }^{\dagger} \text { with } 3 \\
\text { doses of vaccine on } \\
\text { days } 0,3 \text {, and } 7 \text {. } \\
\text { If the animal remains } \\
\text { healthy during the } \\
\text { observation period, } \\
\text { stop treatment. } \\
\text { If the animal } \\
\text { disappears, dies or } \\
\text { becomes rabid, } \\
\text { continue treatment to } \\
\text { complete } 5 \text { doses of } \\
\text { rabies vaccine and use } \\
\text { heterologous anti- } \\
\text { rabies serum. }\end{array}$ & $\begin{array}{l}\text { Wash the site with soap } \\
\text { and water. } \\
\text { Start treatment with } \\
\text { heterologous anti-rabies } \\
\text { serum and } 5 \text { doses of } \\
\text { rabies vaccine on days } 0 \text {, } \\
3,7,14,28 \text {. }\end{array}$ \\
\hline $\begin{array}{l}\text { There are some specific c } \\
\text { State, they are: } \\
\text { * Start treatment with } 2 \text { dos } \\
\text { ** Start treatment with } 2 \text { do } \\
{ }^{\dagger} \text { Start treatment with he } \\
\text { treatment may be suspend }\end{array}$ & gous anti-rabies serum an & $\begin{array}{l}\text { ional Rabies Recommendation } \\
\text { s } 0 \text { and } 3 \text {. } \\
\text { s } 0 \text { and } 3 \text {. } \\
\text { ccine. If the animal is healthy }\end{array}$ & the $10^{\text {th }}$ day after the accident, \\
\hline
\end{tabular}




\section{RE-EXPOSURE RABIES TREATMENT}

A previously immunized person must receive two booster vaccine doses on each of days 1 and 3. If special clinical conditions are present, such as immunosuppression, antimalarial treatment and unsupervised chronic disease, the level of neutralizing antibodies should be assessed 10 days after the last booster vaccine doses $(20,97)$. The recommended schedule for a person previously vaccinated against rabies is complex and the following factors should be considered: number of vaccines previously received; lack of time between the previous treatment and the recent accident; clinical condition of the patient; and kind of vaccine previously used. A normal person under complete treatment should not receive rabies immunoglobulin in re-exposure treatment, because it might interfere with the immune response to the booster vaccine doses (32). The São Paulo technical report on human rabies prophylaxis recommended that the schedule for re-exposure be as shown in Table 6 (20).

Table 6: Re-exposure rabies treatment.

\begin{tabular}{|c|c|c|}
\hline $\begin{array}{l}\text { TIME AFTER PREVIOUS } \\
\text { VACCINATION }\end{array}$ & SCHEDULE & $\begin{array}{c}\text { RECOMMENDED } \\
\text { VACCINATION } \\
\text { (WITH CULTURE CELL RABIES } \\
\text { VACCINE) } \\
\end{array}$ \\
\hline \multirow[t]{2}{*}{ Less than 15 days } & Complete & $\begin{array}{l}\text { Vaccine doses are not } \\
\text { recommended. }\end{array}$ \\
\hline & Incomplete & $\begin{array}{l}\text { Indicate vaccine doses needed to } \\
\text { complete the schedule }\end{array}$ \\
\hline \multirow[t]{3}{*}{ Between 15 and 90 days } & Complete & $\begin{array}{l}\text { Vaccine doses are not } \\
\text { recommended }\end{array}$ \\
\hline & Incomplete - 1 or 2 doses & $\begin{array}{l}\text { Indicate } 4 \text { vaccines doses on day } \\
0,3,7,28 \text {. }\end{array}$ \\
\hline & Incomplete - 3 or 4 doses & Indicate 2 doses on days 0 and 3. \\
\hline \multirow[t]{2}{*}{ After 90 days } & Complete & $\begin{array}{l}\text { Indicate } 2 \text { vaccines doses on } \\
\text { days } 0 \text { and } 3\end{array}$ \\
\hline & Incomplete & Indicate complete schedule \\
\hline
\end{tabular}

Source: Costa et al., 1999 (20).

In case of accidents, patients who have already received pre-exposure prophylaxis can receive the booster vaccine (Table 7$)(13,20)$. 
Table 7: Post-exposure rabies treatment of pre-exposure vaccinated patients.

\begin{tabular}{|c|c|}
\hline $\begin{array}{c}\text { Serological situation (levels of rabies- } \\
\text { neutralizing antibodies) }\end{array}$ & Recommended schedule of rabies vaccine* \\
\hline $\begin{array}{l}\text { With serological dosage; levels }>0.5 \\
\text { IU/ml }\end{array}$ & $\begin{array}{l}\text { Treatment with } 2 \text { doses of rabies vaccine on } \\
\text { days } 1 \text { and } 3\end{array}$ \\
\hline $\begin{array}{l}\text { Without dosage of neutralizing antibodies; } \\
\text { or level of antibodies }<0.5 \mathrm{IU} / \mathrm{ml}\end{array}$ & $\begin{array}{l}\text { Treatment is recommended as for a previously } \\
\text { incompletely treated person }\end{array}$ \\
\hline
\end{tabular}

\section{THE ANIMAL'S CONDITION}

The characteristics of the animal involved in the accident must be evaluated. If a cat or a dog is involved, their health condition before and at the moment of the accident, their provenance (rabies controlled area), and the possibility of laboratory diagnosis must be taken into consideration. In case the animal dies during the observation period, a sample of its nerve tissue should be sent to a reference laboratory. The observation period of 10 days is restricted to dogs and cats. However, the incubation period of the disease ranges from days to months (frequently 60 days) and these animals can eliminate virus through salivation only a few days before the end of the incubation period, normally 2 or 5 days before the onset of symptoms, which may persist until death (89). Wild animals such as any bat species, monkeys, foxes and skunks are considered potential transmitters of rabies. They are not kept under observation because their rabies pathogenesis is unknown (92). When other domestic animals such as cows, pigs, horses, and sheep are involved, human treatment is suggested according to the characteristics of the wound. If the animal dies, it is recommended that a sample of its nerve tissue be sent to the laboratory. Treatment is not considered necessary for accidents caused by rodents or lagomorphs from urban areas or breeding places $(13,20)$.

\section{FUTURE PROSPECTS}

In the middle of the twentieth century, cell culture was adapted for the growth of viruses. The idea of complete inactivation for the development of vaccines arose in the nineteenth century, not long after Pasteur's original insight (98). The advent of genetic engineering has influenced the development of vaccines, providing more opportunities for the production of inactivated antigens and the attenuation of different viruses through direct mutation. Several new strategies including the use of 
vectors, plasmid DNA and lipopeptide vaccines (5) are capable of inducing $C D 4^{+}$and $\mathrm{CD}^{+}$cellular responses. In addition, the paucity of vaccine adjuvants, which until recently were essentially limited to aluminum salts that stimulate $T$ helper type 2 (Th2) response, is at last being corrected by the production of new oil-in-water emulsions, liposomes, tool-like receptor agonists, cytokines, and other substances that direct the immune system to a T helper type 1 (Th1) response $(68,75)$.

Another tendency is the stimulation of innate as well as adaptive immune responses, which can be triggered by appropriate adjuvants such as CpG oligonucleotides (57). Proteomics will probably advance to allow in vitro production of proteins presenting configurations that are more natural. Lipopeptides, a form of peptide vaccines, are currently under intensive investigation because they can generate comprehensive immune responses, without the use of adjuvants. This observation has been confirmed recently in human volunteers who experienced no significant adverse local or systemic manifestations after injection of HIV lipopeptides without adjuvant. One approach is to develop oral vaccines from plants made transgenic for the production of vaccine antigens $(67,85,104)$.

A very important future aspect is the diversification of immunization routes. Many devices have been developed to introduce antigens through the skin. These include patches containing adjuvants applied to lightly abraded skin, and microneedles piercing the stratum corneum. Once past the superficial layer, the antigen comes into contact with dendritic antigen-presenting cells, which migrate to lymph nodes and initiate the immune response $(37,41,66)$.

\section{REFERENCES}

1 ALVAREZ L., FARJADO R., LOPEZ E. Partial recovery from rabies in a nine-yearold boy. Pediat. Infect. Dis. J., 1994, 13, 1154-55.

2 BAER GM., BELLINI WJ., FISHBEIN DB. Rhabdoviruses. In: FIELDS BN., KNIPE DM. Eds. Virology. 2.ed. New York: Raven Press, 1990: 883-930.

3 BALOUL L., LAFON M. Apoptosis and rabies virus neuroinvasion. Biochem., 2003, $85,777-88$.

4 BASGOZ N., FROSCH MP. Case 21-1998. A 32-year-old woman with pharyngeal spasms and paresthesias after a dog bite. N. Eng. J. Med., 1998, 339, 105-12. 
5 BENMCHAMED L., WECHSLER S L., NESBUM A B. Lipopeptide vaccines yesterday, today, and tomorrow. Lancet Infect. Dis., 2002, 2, 425-31.

6 BENVENISTE EN. Inflammatory cytokines within the central nervous system: sources, function and mechanism of action. Am. J. Physiol., 1992, 263, C1C16.

7 BINGHEM J., VAN DER MERWE M. Distribution of rabies antigen in infected material: determining the reliability of different regions of the brain for the rabies fluorescent antibody test. J. Virol. Methods, 2002, 101, 85-94.

8 BOLZAN VL., CUNHA RS. Reações adversas ao soro anti-rábico no ambulatório do Instituto Pasteur de São Paulo, de 1999 a 2005. Braz. J. Infect. Dis., 2005, 9, Suppl 1, S260.

9 BORDIGNON J., BRASIL-DOS-ANJOS G., BUENO C., SALVATIERA-OPORTO J., DÁVILA AMR., GRISARD EC., ZANETTI CR. Detection and characterization of rabies virus in Southern Brazil by PCR amplification and sequencing of the nucleoprotein gene. Arch. Virol., 2005, 15, 695-708.

10 BOTVINKIN DA., POLESCHUK EM., KUZMIN VI., BORISOVA TI., GAZARYAN SV., RUPPRECHT CE. Novel lyssaviruses isolated from bats in Russia. Emerg. Infect. Dis., 2003, 9, 1623-25.

11 BRADAME H., TORDO N. Host switching in Lyssavirus history from the chiroptera to the carnivora orders. J. Virol., 2001, 75, 8096-104.

12 BRASIL. Ministério da Saúde. Agência Nacional de Vigilância Sanitária. Resolução RDC $n^{\circ}$ 153, de 14 de junho de 2004. Regulamento Técnico para Procedimentos Hemoterápicos. Poder Executivo: Diário Oficial da União.

13 BRASIL. Ministério da Saúde. Secretaria de Vigilância à Saúde. Guia de Vigilância Epidemiológica. 6.ed. Brasília: Ministério da Saúde, 2005, 816p. (Série A: Normas e Manuais Técnicos).

14 CECCALDI PE., FILLION MP., ERMINE A., TSIANG H., FILLION G. Rabies virus selectively alters 5-ht1 receptor subtypes in rat brain. Euro. J. Pharmacol., 1993, 245, 129-38. 
15 CENTERS FOR DISEASE CONTROL. Investigation of rabies infections in organ donor and transplant recipients - Alabama, Arkansas, Oklahoma, and Texas, 2004. Morb. Mort. Wkly. Rep., 2004, 53, 1-3.

16 CENTERS FOR DISEASE CONTROL. Mass treatment of humans who drank unpasteurized milk from rabid cows. Morb. Mort. Wkly. Rep., 1999, 48, 22830.

17 CENTERS FOR DISEASE CONTROL. Rabies in laboratory workers. Morb. Mort. Wkly. Rep., 1977, 26, 183-84.

18 CENTERS FOR DISEASE CONTROL. Travelers' Health. Rabies. The Yellow Book. Nat. Center Infect. Dis., 2001-2003.

19 CONSTANTINE DG. Rabies transmission by non-bite route. Public Health Rep., 1962, 77, 287-95.

20 COSTA WA., ÁVILA CA., VALENTINE EJG., REICHMANN MLAB., CUNHA RS., GUIDOLIN R., PANACHÃO RI., OMOTO T., BOLZAN VL. Profilaxia da Raiva Humana. São Paulo: Instituto Pasteur, 1999 (Manuais 4). 33p.

21 CREPIN P., AUNDRY L., ROTIVEL Y., GACOIN A., CAROFF C., BOURHY H. Intravitam diagnosis of human rabies by PCR using saliva and cerebrospinal fluid. J. Clin. Microbiol., 1998, 36, 1177-81.

22 DAHER EF., SILVA JÚNIOR GB., FERREIRA MT., BARROS FAS., GURGEL TM., PATROCÍNIO RMSV. Renal involvement in human rabies: clinical manifestations and autopsy findings of nine cases from northeast of Brazil. Rev. Inst. Med. Trop. S. Paulo, 2005, 47, 315-20.

23 DIETZSCHOLD B., MORIMOTO K., HOOPER DC., SMITH JS., RUPPRECHET CE., KOPROWSKI H. Genotypic and phenotypic diversity of rabies virus variants involved in human rabies: implications for postexposure prophylaxis. J. Hum. Virol., 2000, 3, 50-7.

24 DIETZSCHOLD B., KOPROWSKI H. Screening of organ and tissue donors for rabies. Lancet, 2005, 365, 1305. 
25 DUMRONGPHOL H., SRIKIATKIATKHACHORN A., HEMACHUDHA T., KOTCHABHAKDI N., GOVITRAPONG P. Alteration of muscarinic acetylcholine receptors in rabies viral-infected dog brains. J. Neurol. Sci., $1996,137,1-6$.

26 EMMONS RW., LEONARD LI., DEGENARO FJR. A case of human rabies with prolonged survival. Intervirology, 1973, 1, 60-3.

27 ENRIGHT JB., FRANTI CE., FRYE FL., BEHYMER DE. The effects of corticosteroids on rabies in mice. Can. J. Microbiol., 1970, 16, 667-75.

28 FABET M., PULMANAUSAHAKUL R., HODAWADEKAR SS., SPITSIN S., MCGETTIGAN JP., SCHNELL MJ., DIETZSCHOLD B. Overexpression of the rabies virus glycoprotein results in enhancement of apoptosis and antiviral immune response. J. Virol., 2002, 76, 3374-81.

29 FAZAKERLEY JK., ALLSOPP TE. Programmed cell death in virus infections of the nervous system. Curr. Trop. Microbiol. Immunol., 2001, 253, 95-119.

30 FEKADU M., ENDESHAW T., WONDIMAGEGNEHU A., TESHAGER T., OLSON JG. Possible human-to-human transmission of rabies in Ethiopia. Ethiop. Med. J., 1992, 34, 123-7.

31 FISHBEIN DB., BERNARD KW. Rabies Virus. In: MANDELL GL., BENNETT JE., DOLIN R. Eds. Principles and practice of infectious diseases. New York: Churchill Livingstone, 1995: 1527-43.

32 FISHBEIN DB., ROBINSON LE. Rabies. Brit. Med. J., 1994, 330, 1088-9.

33 FOOKS AR., BROOKES SM., JOHNSON N., MCELHINNEY LM., HUTSON AM. European bat lyssaviruses: an emerging zoonosis. Epidemiol. Infect., 2003, $131,1029-39$.

34 FRAZATTI-GALLINA NM., MOURÃO-FUCHER RM., PAOLI RL., SILVA MLN., MIYAKI C., VALENTIN EJG., RAW I., HIGASHI HG. Vero cell rabies vaccine produced using serum-free medium. Vaccine, 2004, 20, 511-17.

35 FU ZF., WINE E., ZENG YM., SHAFER MH., SHENG H., CORISDE OS., RAUSCHER FJ., KOPROWSKI H., DIETZSCHOLD B. Differential effects of rabies and Borna disease viruses on immediate-early- and late-response gene expression in brain tissues. J. Virol., 1993, 67, 6674-81. 
36 GIBBONS RV. Cryptogenic rabies, bats, and the question of aerosol transmission. Ann. Emerg. Med., 2002, 39, 528-36.

37 GLENN GM., KENNEY RT., ELLINGSWORTH LR., FRECH SA., HAMMOND SA., ZOETEWEIJ JP. Transcutaneous immunization and immunostimulant strategies: capitalizing on the immunocompetence of the skin. Expert. Rev. Vaccines, 2003, 2, 253-67.

38 GODE GA., RAJU AV., JAYALAKSHMI TS., KAUL HI., BIDE NK. Intensive care in rabies therapy: clinical observation. Lancet, 1976, 2, 6-8.

39 GODE GA., SAKSENA R., BATRA RK., KALIA PK., BHIDE NK. Treatment of 54 clinically diagnosed rabies patients with two survivals. Indian J. Med. Res., 1998, 88, 564-6.

40 GRIFFIN DE., HARDWICK JM. Perspective: virus infections and the death of neurons. Trends Microbiol., 1999, 7,155-60.

41 HAMMOND AS., WELWENDER D., ALVING CR., BLEEN GM. Transcutaneous immunization: $T$ cell response and boosting of existing immunity. Vaccine, 2001, 19, 2701-7.

42 HATTWICK MA., WEISS TT., STECHSCHULTE CJ., BAER GM., GREGG MB. Recovery from rabies: a case report. Ann. Intern. Med., 1972, 76, 931-42.

43 HELLENBRAND W., MEYER C., RASCH G., STEFFENS I., AMMON A. Cases of rabies in Germany following organ transplantation. Eurosurveillance Weekly Release: E-alert 18 February, 2005, 10, 050217.

44 HELMICK CG., TAUXE RV., VERNON AA. Is there a risk to contacts of patients with rabies? Rev. Infect. Dis., 1987, 9, 511-18.

45 HEMACHUDHA T., LAOTHAMATAS J., RUPPRECHT CE. Human rabies: a disease of complex neuropathogenic mechanism and diagnostic challenges. Lancet Neurol., 2002, 1, 101-9.

46 HEMACHUDHA T., PHANUPHAK P., SRIWANTHANA B. Immunologic study of human encephalitic and paralytic rabies: preliminary report of 16 patients. Am. J. Med., 1988, 84, 673-7. 
47 HEMACHUDHA T., WACHARAPLUERSADEE S. Antemortem diagnosis of human rabies. Clin. Infect. Dis., 2004, 39, 1085-6.

48 HOOPER DC., MORIMOTO K., BETTE M., WEIHE M., KOPROWSKI H., DIETSHCHOLD B. Collaboration of antibody and inflammation in the clearance of rabies virus from the CNS. J. Virol., 1998, 72, 3711-19.

49 IWASAKI Y., GERHAD W., CLARK HF. Role of host immune response in the development of either encephalitic or paralytic disease after experimental rabies infection in mice. Infect. Immun., 1997, 18, 220-5.

50 JACKSON AC. Cholinergic system in experimental rabies in mice. Acta Virol., $1993,37,502-8$.

51 JACKSON AC. Rabies virus infection: an update. J. Neurovirol., 2003, 9, 253-8.

52 JACKSON AC., WARRELL MJ., RUPPRECHT CE., ERTL HCJ., O'REILLY M., DIETZSCHOLD B., LEACH RP., FU ZF., WUNNER WH., BLECK TP., WILDE H. Management of rabies in humans. Clin. Infect. Dis., 2003, 36, 60-3.

53 JADAVI M., FAYAZ A., MIRDEHGHAN SA., AINOLLAHI B. Transmission of rabies by corneal graft. Cornea., 1996, 15, 431-3.

54 JOINT OF UNITED KINGDON BLOOD TRANSFUSION AND TISSUE TRANSPLANTATION SERVICES. Rabies and blood transfusion/tissue transplantation. Guidelines for the appropriate selection of blood donors in the UK, [serial online], 2005. Position Statement 08. Available from: (http://transfusionguidelines.org.uk/index.asp?Publication=DL\&Section=12\&pa geid=808)

55 KAPLAN MM., WIKTOR TJ., KOPROWSKI $H$. Pathogenesis of rabies in immunodeficient mice. J. Immunol., 1975, 114, 1761-5.

56 KARLINER JS., BELAVAL GS. Incidence of reactions following administration of anti-rabies serum. Study of 526 cases. J. Am. Med. Assoc., 1965, 5, 109-12.

57 KLINMAN DM. Immunotherapeutic uses of CgG oligonucleotides. Nat. Rev. Immunol., 2004, 4, 249-58.

$58 \mathrm{KOCH}$ KJ., SAGARTZ JW., DAVIDSON D., LAWHASWAHS K. Diagnosis of human rabies by cornea test. Am. J. Clin. Pathol., 1975, 63, 509-15. 
59 KOPROWSKI H., ZENG YM., HEBES-KATES E., FRASER N., RORKE L., FU ZF., HANLON C., DIETZSCHOLD B. In vivo expression of inducible nitric oxide synthase in experimentally induced neurologic disease. Proc. Natl. Acad. Sci. USA, 1993, 90, 3024-32.

60 KUZMIN VI., ORICIARI LA., ARAI YT., SMITH JS., HANLON CA., RUPPRECTH CE. Bat lyssaviruses (Aravan and Khujand) from Central Asia: phylogenetic relationships according to N, P and G genes sequences. Virus Res., 2003, 97, 65-79.

61 LIMA ER., RIET-CORREA F., CASTRO RS., GOMES AAB., LIMA FS. Sinais clínicos, distribuição das lesões no sistema nervoso e epidemiologia da raiva em herbívoros na região Nordeste do Brasil. Braz. J. Vet. Res., 2005, 25, 25064.

62 LOCKHART BP., TORDO N., TSIANG H. Inhibition of rabies virus transcription in rat cortical neurons with the dissociative anesthetic ketamine. Antimicrobiol. Agents Chemother., 1992, 36, 1750-5.

63 MADHUSUDANA SN., NAGARAJ D., UDAY N., RATNAVALLI E., KUMAR MV. Partial recovery from rabies in a six-year-old girl. Int. J. Infect. Dis., 2002, 6, 85-6.

64 MAZARAKIS ND., AZZOUZ M., ROHELL JB. Rabies virus glycoprotein pseudotyping of lentiviral vectors enables retrograde axonal transport and access to the nervous system after peripheral delivery. Hum. Mol. Genet., 2001, 10, 2109-21.

65 MESSENGER SL., SMITS JS., RUPPRECHT CE. Emerging Epidemiology of Batassociated cryptic cases of rabies in humans in the United States. Clin. Infect. Dis., 2002, 35, 738-47.

66 MIKSZTA JA., ALARCON JB., BRITTINGHAM JM., SUTTER DE., PETTIS RJ., HARVEY NG. Improved genetic immunization via micro-mechanical disruption of skin-barrier function and target epidermal delivery. Nat. Med., 2002, 8, 41519. 
67 MODELSKA A., DIETZSCHOLD B., SLPYSH N., FU ZF., STEPLEWSKI K., HOOPER DC., KOPROWISKI H., YUSIBOV V. Immunization against rabies with plant-derived antigen. Proc. Natl. Acad. Sci. USA, 1998, 95, 2481-85.

68 MOINGEON L., HAENSLER J., LINDENBERG A. Towards the rational dosing of Th1 adjuvants. Vaccine, 2001, 19, 4363-72.

69 MONTAGNON B., FANGET B. Purified Vero cell vaccine for humans. In: MESLIN FX., KAPLAN MM. Laboratory Techniques in Rabies. Koprowski. 4.ed. WHO Library Cataloguing in Publication Data: 1996, p.285-91.

70 MORTIERE MD., FALCONE AL. An acute neurologic syndrome temporally associated with postexposure treatment of rabies. Pediatrics, 1997, 100, 720 1.

71 MULLER EE., NISTIC OE. Brain messengers and the pituitary. New York: Academic Press, 1988.

72 NATIONAL ADVISORY COMMITTEE ON IMMUNIZATION. Update on Rabies Vaccine. Can. Commun. Dis. Rep., 2005, 1, 1-8.

73 NICHOLSON KG., FARROW PR., BIJOUK V. Pre-exposure studies with purified chick embryo cell culture rabies vaccine and human diploid cell vaccine. Serological and clinical response in man. Vaccine, 1997, 5, 208-10.

74 NICHOLSON KG. Cell-culture vaccines for human use: general considerations. In: MESLIN FX., KAPLAN MM., KOPROWSKI H. Eds. Laboratory Techniques in Rabies. 4.ed. Geneva: World Health Organization, 1996: 272-9.

75 O'GARRA A., VIEIRA P. Regulatory T cells and mechanisms of immune system control. Nat. Med., 2004, 10, 801-5.

76 PORRAS C., BARBOZA JJ., FUENZALIDA E., ADAROS HL., OVIEDO AM., FURST J. Recovery from rabies in man. Ann. Intern. Med., 1976, 85, 44-8.

77 PORTER RH., GREENAMYRE Jl. Regional variations in the pharmacology of NMDA receptor channel blockers: implications for therapeutic potential. $J$. Neurochem., 1995, 64, 614-23.

78 PRABHAKAR BS., NATHANSON N. Acute rabies death mediated by antibody. Nature, 1981, 290, 590-1. 
79 PRÉHAUD C., LAY S., DIETZSCHOLD B., LAFON M. Glycoprotein of nonpathogenic rabies viruses is a key determinant of human cell apoptosis. $\mathrm{J}$. Virol. 2003, 77, 10537-47.

80 PRESSUTI RJ. Treatment and prophylaxis against infectious complications. Postgrad. Med. J., 1997, 101, 243-52.

81 RUPPRECHT CE., HANLON CA., HEMACHUDHA T. Rabies re-examined. Lancet Infect. Dis., 2002, 2, 327-43.

82 SMITH JS., McCELLAND CL., REID FL., BAER GM. Dual role of the immune response in street rabies virus infection of mice. Infect. Immun., 1982, 35, 21321.

83 SRINIVASON A., BURTON EC., KUEHNERT MJ., RUPPRECHT CE., SUTKER WL., KSIAZEK TG., PADDOCK CD., GUARNER J., SHIEH WJ., GOLDSMITH C., HANLON N., ZORETIC J., FISCHBACH B., NIEZGODA M., EL-FEKY WH., ORCIARI L., SANCHEZ EQ., LIKOS A., KLINTMALM G.B., CARDO, D., LEDUC J., CHAMBERLAND ME., JERNIGAN DB., ZAKI SR. Transmission of rabies virus from an organ donor to four transplant recipients. N. Eng. J. Med., 2005, 352, 1103-11.

84 SUGAMATA M., MIYAZAWA M., MOR S., SPANGRUDE GJ., EWALT LC., LODMELL DL. Paralysis of street rabies virus-infected mice is dependent on $\mathrm{T}$ lymphocytes. J. Virol., 1992, 66, 1252-60.

85 TACKED CO. Garden-variety vaccines: antigens derived from transgenic plants. Exp. Rev. Vaccine, 2004, 3, 529-31.

86 TALAN DA., CITRON DM., ABRAHAMIAN FM., MORAN GJ., GOLDSTEIN EJC. Bacteriologic analysis of infected dog and cat bites. New Eng. J. Med., 1999, 340, 85-92.

87 TAM RC., LAU JY., HONG Z. Mechanisms of action of ribavirin in antiviral therapies. Antivirol. Chem. Chemother., 2001, 12, 261-72.

88 TANTAWICHIESN T., BENJAVONGKULCHAI M., WILDE H., JAIJAROENSUP W., SIAKASEM A., CHAREONWAI S., YOUNTONG C. Value of skin testing for predicting reactions to equine rabies immune globulin. Clin. Infect. Dis., $1995,21,660-2$. 
89 TEPSUMETHANON V., LUMERTDACHA B., MIMOONPITAK C., WILDE $\mathrm{H}$. Clinical diagnosis for rabies in live dogs. In: WORLD CONGRESS OF THE WORLD ANIMALS VETERINARIAN ASSOCIATION, 28, Bangkok, 2003. Proceedings... Bangkok, 2003.

90 THOULOUZE MI., LFAGE M., MONTANO-HIROSE JA., LAFON M. Rabies virus infects mouse and human lymphocytes and induces apoptosis. J. Virol., 1997, $71,7372-80$.

91 TINLINE RR. Persistence of rabies in wildlife. In: CAMPBELL JB., CHARLTON JM. Eds. Rabies. London: Kluwer Academic Publ., 1985: 301-22.

92 TSIANG H. Neuronal function impairment in rabies-infected rat brain. J. Gen. Virol., 1982, 61, 277-81.

93 UBOL S., SUKWATTANAPAN C., MANEERAT Y. Inducible nitric oxicide synthase inhibition delays death of rabies virus-infected mice. J. Med. Microbiol., 2001, 50, 238-42.

94 WARRELL MJ., WARRELL DA. Rabies and other lyssaviruses disease. Lancet, 2004, 363, 959-69.

95 WORLD HEALTH ORGANIZATION. Current WHO GUIDE for rabies pre and post-exposure treatment in humans. WHO Department of Communicable Surveillance and Response, 2002. 23p.

96 WORLD HEALTH ORGANIZATION. Expert Committee on Rabies. 8. Report. Geneva: WHO Tech. Rep. Series, 1992, 824. 87p.

97 WORLD HEALTH ORGANIZATION. Expert Consultation on Rabies. 1. Report. Geneva: WHO Tech. Rep. Series, 2004, 931. 121p.

98 WIKTOR TJ., FERNANDES MV., KOPROWSKI H. Cultivation of rabies virus in human diploid cell strain WI38. J. Immunol., 1964, 93, 353-66.

99 WILDE H., CHUTIVONGSE S. Equine rabies immunoglobulin: a product with an underserved poor reputation. Am. J. Trop. Med. Hyg., 1990, 42, 175-8.

100 WILDE H., THIPKONG P., SITPRIJA V., CHAIYABUTR N. Heterologous antisera and antivenins are essential biological: perspectives on worldwide crises. Ann. Intern. Med., 1996, 125, 233-6. 
C. A. Consales and V. L. Bolzan RABIES REVIEW: IMMUNOPATHOLOGY, CLINICAL ASPECTS AND TREATMENT. J. Venom. Anim. Toxins incl. Trop. Dis., 2007, 13, 1, p. 38

101 WILLOUGHBY RE., TIEVES KS., HOFFMAN GM., GHANAYEM NS., AMLIELEFOND CA., SCHWABE MJ., CHUSID MJ., RUPPRECHET CE. Survival after treatment of rabies with induction of coma. New Eng. J. Med., 2005, 352, 2508-14.

102 WINKLER WG., FASHINELL TR., LEFFINGWELL L., HOWARD P., CONOMY JP. Airborne rabies transmission in a laboratory worker. J. Am. Med. Assoc., $1973,226,1219-21$.

103 XIANG ZQ., KNOWLESS BB., MCCARICK JW., ERTH HC. Immune effectors mechanisms required for protection to rabies virus. Virology, 1995, 214, 398404.

104 YUSIBOV V., HOOPER DC., STITSIN SV., FLEYSH N., KEAN RB., MIKHEEVA T., DEKA D., KARASEV A., COX S., RANDALL J., KOPROWSKI H. Expression in plants and immunogenicity of plant virusbased experimental rabies vaccine. Vaccine, 2002, 20, 3155-64. 